\title{
Computation of vapour pressure deficit and crop transpiration via development of a web based computer module
}

\author{
MAHESH CHAND SINGH ${ }^{1 *}$, J. P. SINGH ${ }^{1}$, K. G. SINGH ${ }^{1}$, O. P. GUPTA ${ }^{2}$ and G. KUMAR ${ }^{2}$ \\ ${ }^{1}$ Dept of Soil and Water Engineering, ${ }^{2}$ Dept of Electrical Engineering and Information Technology, \\ Punjab Agricultural University, Ludhiana, Punjab, India \\ *Corresponding Author email : msrawat@pau.edu
}

\begin{abstract}
The plant water or nutrient requirement under greenhouse conditions is mainly governed by crop transpiration in a linear relation to vapour pressure deficit (VPD), particularly in soilless production systems. Being a cooling process in plants, transpiration governs the plant water requirement in relation to the subjected microclimatic conditions and VPD can be used as a tool to maintain greenhouse crop transpiration to optimal range for obtaining desired crop yields. Thus, the present investigation was undertaken to study the integrated effect of temperature $\left(T_{\text {apc }}\right)$, relative humidity $\left(\mathrm{E}_{\text {apc }}\right)$ and solar radiation $\left(\mathrm{I}_{\mathrm{rad}}\right)$ on VPD and crop transpiration. A computer module was developed to monitor the behavior of the VPD and thereby the crop transpiration through charts under greenhouse conditions. The VPD indicated a linear increasing trend with $T_{\text {apc }}\left(R^{2} \geq 0.84\right)$ and decreasing trend with $\mathrm{E}_{\text {apc }}\left(\mathrm{R}^{2}=0.99\right)$, demonstrating a strong correlation in both cases. The increasing crop transpiration with VPD, particularly under hot climatic conditions significantly increased the input water and nutrient requirements of the crop. Thus, transpiration in relation to VPD should be considered as a factor for fertigation scheduling and improving irrigation control in soilless systems. Moreover, maintaining $\mathrm{T}_{\text {apc }}, \mathrm{E}_{\text {apc }}$ and VPD within range of $22-27^{\circ} \mathrm{C}, 60-80 \%$ and $0.53-1.10 \mathrm{kPa}$ may help to control the crop transpiration, manage the greenhouse irrigation and fertigation, and thus improve the cucumber yield.
\end{abstract}

Key words: Greenhouse, relative humidity, solar radiation, VPD, transpiration, temperature

Vapour pressure deficit (VPD) is considered as an important factor affecting the plant growth and development under greenhouse conditions. It is mainly governed by $\mathrm{T}_{\text {apc }}, \mathrm{E}_{\text {apc }}$ and $\mathrm{I}_{\mathrm{rad}}$ inside a greenhouse (Singh et al., 2017; Singh et al., 2018). It affects the crop transpiration inside greenhouse (Jolliet and Bailey, 1992) and thus the irrigation control. Under low VPD, transpiration rate from plants is also lower. While under high VPD, plants contribute to higher transpiration rates and greater water stress. The increased VPD in relation to higher temperature works against the effect of stomatal closure, when $\mathrm{CO}_{2}$ enrichment is done (Nederhoff et al., 1992). The elevated VPD values can hamper the photosynthesis, the plant growth, dry-matter accumulation and ultimately the crop yield (Deiveegan et al., 2019). The fruit yield of cucumber reduces with increased VPD in relation to higher $\mathrm{E}_{\text {apc }}$ (Bakker, 1991). According to Singh et al. (2017), VPD values from 0.53 to $1.10 \mathrm{kPa}$ are most favorable for optimal plant growth and fruit development of cucumber. Thus, VPD can be used as a tool to maintain the greenhouse crop transpiration to an optimal range for obtaining maximum crop yield (Srivastava et al., 2010; Kumar et al., 2019).

Transpiration plays a significant role in irrigation management under protected conditions. It is related to VPD (even for values $\geq 2.5 \mathrm{kPa}$ ) in linear trend (Medrano et al., 2005; Singh et al., 2017). The higher transpiration rate, chiefly under hot climatic conditions appreciably increases the plant water requirements. The knowledge of crop transpiration may possibly aid to advance the irrigation management of soilless cultivation under protected structures (Medrano et al., 2005). Transpiration is directly dependent on solar radiation reaching above the plant community. It has been considered as one of the important components of energy balance of a plant. The development of plants is directly connected to the water availability to them either in the plant tissues or as water 
vapour in the air. Thus, it becomes imperative to monitor and control water application in greenhouse crops, water uptake by plant root system, internal water transport and the external transfer through transpiration. The present investigation was undertaken to study the trend in VPD via developing a computer module and its effect on crop transpiration of soilless cucumber in relation to subjected greenhouse microclimatic conditions.

\section{MATERIALS AND METHODS}

\section{Experimental description}

Cucumbers were cultivated in soiless media (coco-peat) inside a naturally ventilated greenhouse located at the Research Farm of Department of Soil and Water Engineering, Punjab Agricultural University, Ludhiana. The study site is located between latitude of $30^{\circ} 56^{\prime} \mathrm{N}$ and longitude of $75^{\circ} 52^{\prime} \mathrm{E}$ with an altitude of $247.0 \mathrm{~m}$ above mean sea level. The entire surface area of the greenhouse floor was covered with a mat for avoidance of weed emergence. Cucumbers were cultivated for two growing seasons viz. season 1: September 2016 to January 2017 and season 2: February to May 2017. The nursery of cucumbers was raised under a poly net house for two successive seasons. The vertically trained plants (through the strings attached to roller hooks with overhead wire) were nourished with nutrient solution on daily basis for a pre-decided time. The web based computer module for easy depiction of VPD through gerenation of charts was developed in the Department of Electrical Engineering and Information Technology, College of Agricultural Engineering, PAU Ludhiana. The greenhouse under experimentation has been described in Table 1 .

\section{Data recording and computation}

The weather data on solar radiation, temperature and relative humidity both inside and outside the greenhouse under experimentation were recorded using the sensors through data logger (Table 2). The computed VPD was compared with the values obtained using the formula reported in Arellano et al. (2006). The crop transpiration was calculated using the equation derived from Penman-Monteith equation as reported in Medrano et al. (2005) with certain modifications in coefficients.

\section{Computer module for VPD calculations under greenhouse conditions}

A web based computer module for assisting in the basic calculation of vapour pressure deficit using the formulas given in Table 3 was developed. This module also included sub-module for uploading CSV file for data input in bulk and generate graphical representation in the form of Excel Chart for easy depiction (Fig.1).

The technology used in development of this modlue includes the followings:

- FrontEnd (HTML, CSS, JavaScript)

- Frameworks [JQuery(A javascript Framework), CanvasJS (A javascript Chart Library) and Bootstrap Framework(Styling HTML Elements)]

- BackEnd (PHP, MySQL)

\section{RESULTS AND DISCUSSION}

\section{VPD behaviour}

The Fig. 2 and 3 demonstrate the variation of VPD deficit computed by the developed module and its comparison with Singh et al. (2018) and Arellano et al. (2006). During season 1, the diurnal VPD was decreasing in trend with progress of the growing season. For example, on dates viz. 10 $0^{\text {th }}$ October 2016, $10^{\text {th }}$ November 2016 and $10^{\text {th }}$ December 2016, the VPD was computed to be in the range of $0.03-1.45 \mathrm{kPa}, 0.01-0.79 \mathrm{kPa}$ and $0.01-1.27$ $\mathrm{kPa}$, respectively having upper limits between 13:00 hr to 16:00 hr on daily basis (Fig. 4). A significant decrease in daytime VPD was observed between $10^{\text {th }}$ October and $10^{\text {th }}$ November, 2016. However, between $10^{\text {th }}$ November and $10^{\text {th }}$ December 2016, the VPD first decreased from 09:00 hr to $11: 00 \mathrm{hr}$ and then increased from 11:00 hr to 05:00 hr due to variations in outside weather conditions. VPD was computed to be maximum at maximum temperature and with minimum relative humidity.

During season 2 in 2017, VPD augmented rapidly with advancement in the growth season, particularly from Mid-March onward, chiefly due to increased temperature and decreased relative humidity. For example, on dates viz. $1^{\text {st }}$ March 2017, $1^{\text {st }}$ April, 2017 and $1^{\text {st }}$ May 2017, the VPD was computed to be in the range of $0.01-2.74$ 
Table 1: Description of the greenhouse under experimentation

\begin{tabular}{ll}
\hline Greenhouse features & \\
\hline Greenhouse type & $\begin{array}{l}\text { Naturally ventilated } \\
\text { greenhouse }\end{array}$ \\
North-South dimension (m) & 28.0 \\
East-West dimension (m) & 20.0 \\
Floor area of greenhouse $\left(\mathrm{m}^{2}\right)$ & 560.0 \\
Orientation of greenhouse & North-South \\
Covering material os greenhouse & UV stabilized \\
polyethylene \\
Thickness of cover ( $\mu$ m) & 200.0 \\
Number of spans & 02 \\
Slope given to the greenhouse & $1.0 \%$ (North-South) \\
floor & 4.5 \\
Gutter height (m) & 6.5 \\
Ridge height (m) & $69.0 \%$ \\
Average transmissivity of cover & None \\
Heating system used & Natural \\
Type of ventilation used & 40.0 mesh insect- net \\
Insect net used for natural & $20.0 \%$ (adjustable) \\
ventilation & $10.0 \%$ (fixed) \\
Side ventilation (natural) area & Fixed top ventilation (natural) \\
area & \\
Height at which foggers were & $2.0 \mathrm{~m}$ above floor \\
installed & \\
Height at which shade net is & $2.8 \mathrm{~m}$ above floor \\
installed & 384.0 \\
Area under shade net ( ${ }^{2}$ ) & \\
\hline &
\end{tabular}

$\mathrm{kPa}, 0.02-2.79 \mathrm{kPa}$ and $0.26-4.55 \mathrm{kPa}$, respectively having upper limits between 13:00 to 14:00 hr (Fig. 1). The increased VPD with the progress of growing season 2 significantly affected the plant growth and requirement of nutrient solution through its direct relationship with crop transpiration. The VPD in the range of $0.53-1.10 \mathrm{kPa}$ was recorded to be suitable for optimal plant development (Table 4).

\section{Effect of $T_{a p c}, E_{a p c}$ and $I_{r a d}$ on VPD}

VPD was observed to be related linearly to $T_{\text {apc }}$ and $\mathrm{E}_{\text {apc }}$, while non-linearly to solar radiation throughout the crop growth period (Fig. 5 and 6). VPD increased $\left(\mathrm{R}^{2}=0.85\right)$ with $\mathrm{T}_{\text {apc }}$ and decreased linearly $\left(\mathrm{R}^{2}=0.99\right)$ with $\mathrm{E}_{\text {apc }}$. For example, on 01.01.2017 (Fig. 5a), the highest value of VPD $(1.44 \mathrm{kPa})$ was computed to be at $23.4^{\circ} \mathrm{C}$ $\left(\mathrm{T}_{\text {apc }}\right), 55.9$ per cent $\left(\mathrm{E}_{\text {apc }}\right)$ and $0.0612 \mathrm{kWm}^{-2}\left(\mathrm{I}_{\text {rad }}\right)$. Even in the absence of the crop (Fig. 5b), the trend was similar for VPD with respect to $\mathrm{T}_{\text {apc }}, \mathrm{E}_{\text {apc }}$ and $\mathrm{I}_{\text {rad }}$ for a duration of 24 hours (diurnal variation) having $\mathrm{R}^{2}$ values of $0.90,0.99$

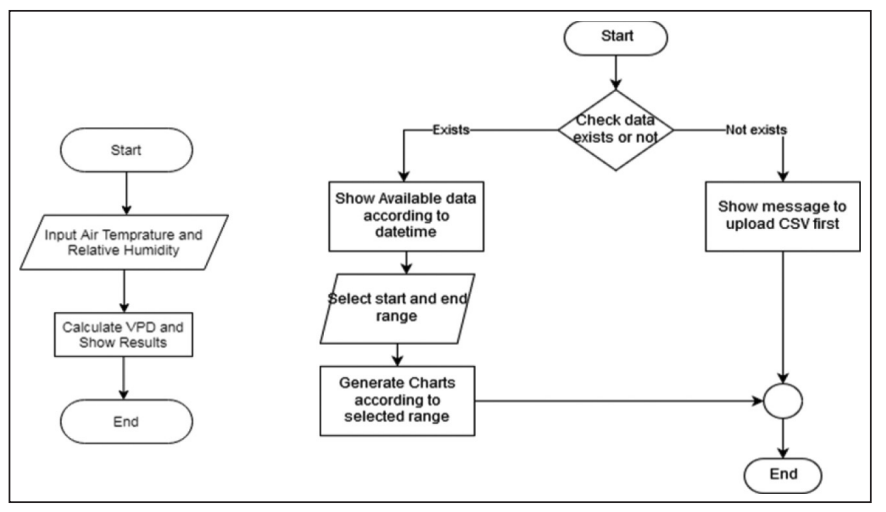

Fig. 1: Data flow diagram and generation of charts

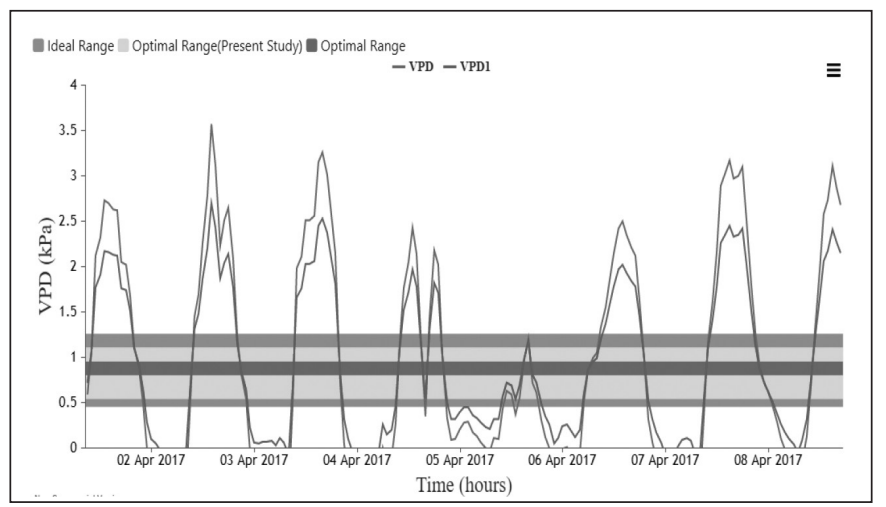

Fig. 2: Graphical representation of VPD (through module)

and 0.69 , respectively. However, the maximum value of VPD $(1.09 \mathrm{kPa})$ was attained at $21.5^{\circ} \mathrm{C}\left(\mathrm{T}_{\text {apc }}\right), 60.4$ per cent $\left(\mathrm{E}_{\text {apc }}\right)$ and $0.073 \mathrm{kWm}^{-2}\left(\mathrm{I}_{\text {rad }}\right)$.

\section{Transpiration}

The transpiration rate was directly affected by the solar intensity; $\mathrm{T}_{\text {apc }}$ and day time (Fig. 7). During season 1 of 2016, the transpiration from crop increased with increasing plant canopy area and ultimately decreased as a result of decreased $\mathrm{T}_{\mathrm{apc}}$ with the progress of the season. For example, on dates viz. $27^{\text {th }}$ December 2016 and $8^{\text {th }}$ January 2017, the highest transpiration value was obtained to be $186.5 \mathrm{gm}^{-2} \mathrm{hr}^{-1}$ and $150.7 \mathrm{gm}^{-2} \mathrm{hr}^{-1}$ at $02: 00 \mathrm{hr}$ and 01:00 hr, respectively. While, during season of 2017, the transpiration augmented rapidly with advancement in the season in relation to mounting $\mathrm{T}_{\text {apc }}$. For example, on dates viz. 23 ${ }^{\text {rd }}$ March 2017, 13 ${ }^{\text {th }}$ April 2017 and $4^{\text {th }}$ May 2017 , the maximum value of transpiration was computed to be $55.80,305.10$ and $423.60 \mathrm{gm}^{-2} \mathrm{hr}^{-1}$ at $11: 00,02: 00$ 
Table 3: Computation of VPD, transpiration and stomatal conductance or resistance

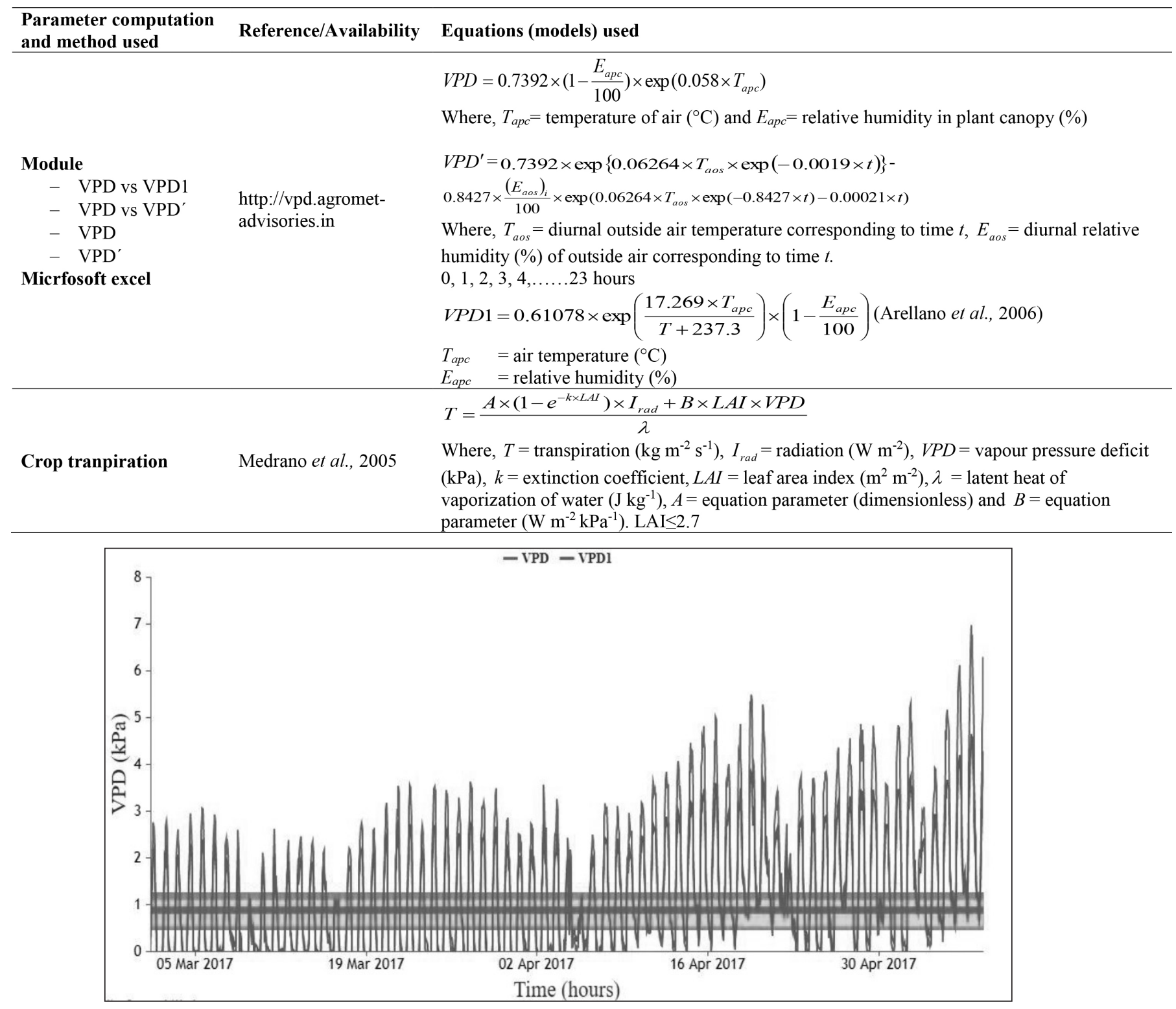

Fig. 3: Graphical representation of VPD for season 2 (through module)

and 15:00 hr, respectively.

\section{Variation of transpiration with VPD}

Transpiration increased linearly with VPD and vice-versa. Transpiration was also a function of LAI and increased with increasing LAI. Both transpiration and VPD were computed to be highest during day solar hours, generally between 12:00 hr and 03:00 hr. For example, on dates viz., $1^{\text {st }}$ March 2017, $1^{\text {st }}$ April 2017 and $1^{\text {st }}$ May 2017, the maximum and minimum values of transpiration and VPD were computed to be 207.1, 224.9 and 328.1 $\mathrm{gm}^{-2} \mathrm{hr}^{-1}$ and $2.7,2.8$ and $4.5 \mathrm{kPa}$, respectively (Fig. 8).
Transpiration was highly correlated with VPD in each case $\left(R^{2} \geq 0.95\right)$.

A strong linear positive relationship existed between VPD and crop transpiration (Fig. 5). At higher VPD, transpiration became unlimited due to increased evaporative demand and rssulted in drying out of the plants. However, at lower VPD, transpiration was limited. During this study period, both $\mathrm{T}_{\text {apc }}$ and $\mathrm{E}_{\text {apc }}$ were significantly affected with operation of thermal shade net/ screen, which in turn affected VPD and transpiration, and hence the crop water or nutrient requirement. The drop or 
Table 4: Optimal range of climatic parameters for greenhouse cucumber cultivation

\begin{tabular}{lccc}
\hline \multirow{2}{*}{ Parameter } & \multicolumn{3}{c}{ Desirable range } \\
\cline { 2 - 4 } & Present study & \multicolumn{2}{c}{ Literature } \\
$\mathrm{T}_{\text {apc }}\left({ }^{\circ} \mathrm{C}\right)$ & $22.0-27.0$ & Day: $23.9-26.7^{\circ} \mathrm{C}$ & Johnson and Hickman 1984 \\
$\mathrm{E}_{\text {apc }}(\%)$ & $60.0-85.0$ & Night: $21.1-23.9^{\circ} \mathrm{C}$ & - \\
$\mathrm{I}_{\text {rad }}\left(\mathrm{kWm}{ }^{-2}\right)$ & $0.100-0.169$ & - & - \\
$\mathrm{VPD}(\mathrm{kPa})$ & $0.53-1.10$ & Between 0.8 and $0.95 \quad$ (Ideal range, $0.45-$ & Anon $(2017 \mathrm{c})$ \\
\hline
\end{tabular}

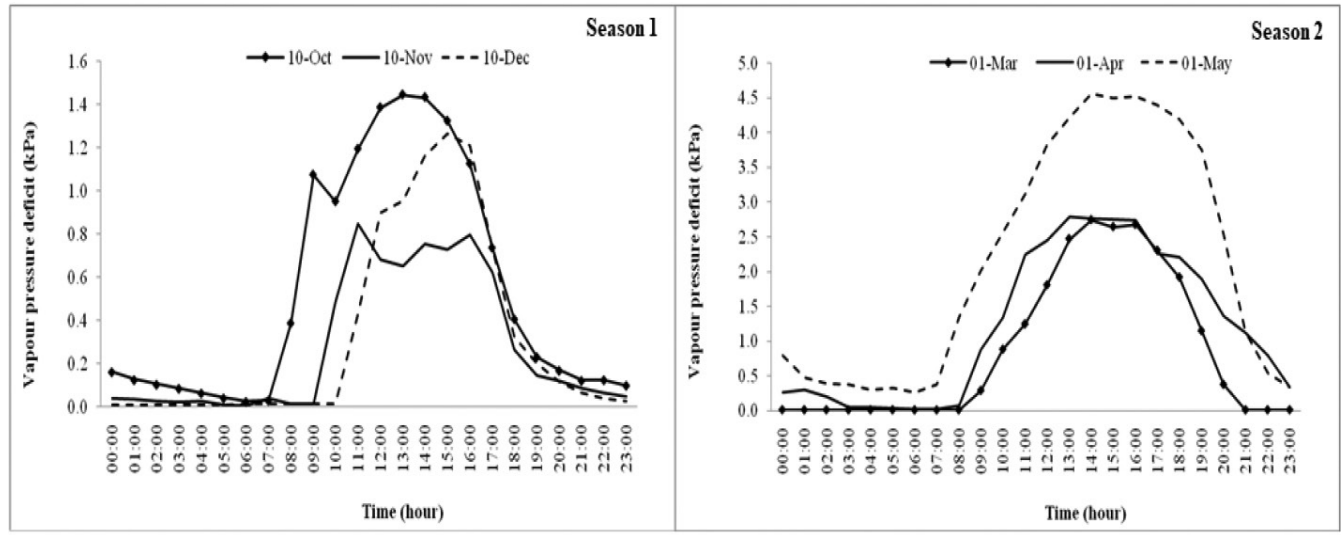

(a)

(b)

Fig. 4: Diurnal variation in VPD during a) season 1 and b) season 2 (Singh et al 2017)

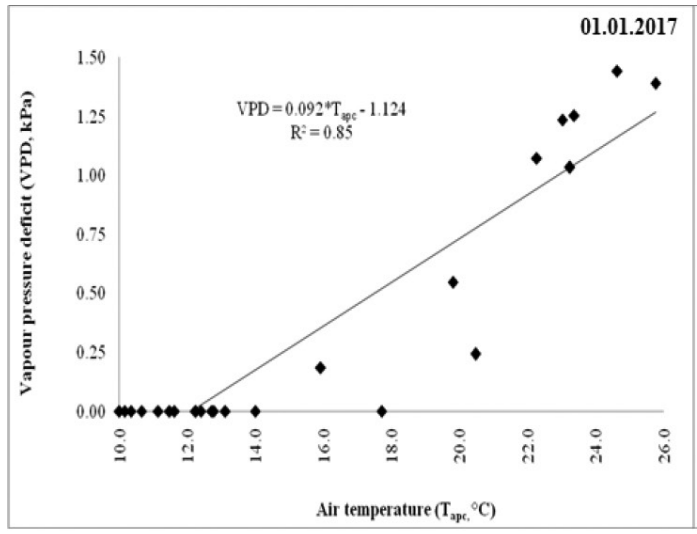

(a)

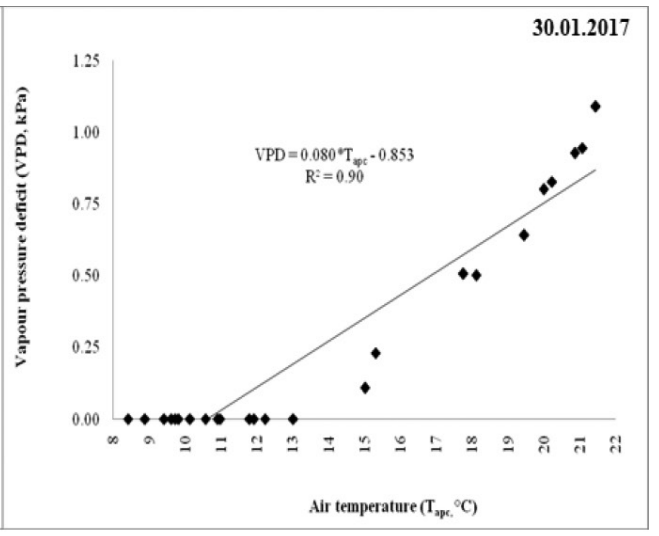

(b)

Fig. 5: Variation of vapour pressure VPD with $\mathrm{T}_{\text {apc }}$ on a) 01.01.2017 and b) 30.01.2017

rise in VPD was also found as a function of ventilation rate (side natural ventilation), which significantly affected the $\mathrm{T}_{\text {apc }}$ and $\mathrm{E}_{\text {apc }}$ inside of the greenhouse. VPD of air in the plant community increased due to increase in rate of air exchange through natural ventilation. A similar observation has also been reported in Jolliet and Bailey (1992). The cucumber yield was affected with variation in VPD and thereby the transpiration in relation to fluctuation in $\mathrm{T}_{\text {apc }}$ and $\mathrm{E}_{\mathrm{apc}}$. Similar effect of VPD and crop transpiration on crop yield has been reported in ElAidy (1990) and Sumathi et al. (2008). The operation of thermal shade net and natural ventilation rate had a significant effect on greenhouse microclimate (mainly on $\mathrm{I}_{\mathrm{rad}}, \mathrm{T}_{\mathrm{apc}}$ and $\mathrm{E}_{\mathrm{apc}}$ ) and indirectly on VPD and crop transpiration. $\mathrm{I}_{\mathrm{apc}}, \mathrm{T}_{\mathrm{apc}}$ and $\mathrm{E}_{\mathrm{apc}}$ had a significant effect on VPD and the crop transpiration. Apart from using shade screen, the lower values of solar radiation (low light) inside the greenhouse were sometimes due to cloudy 


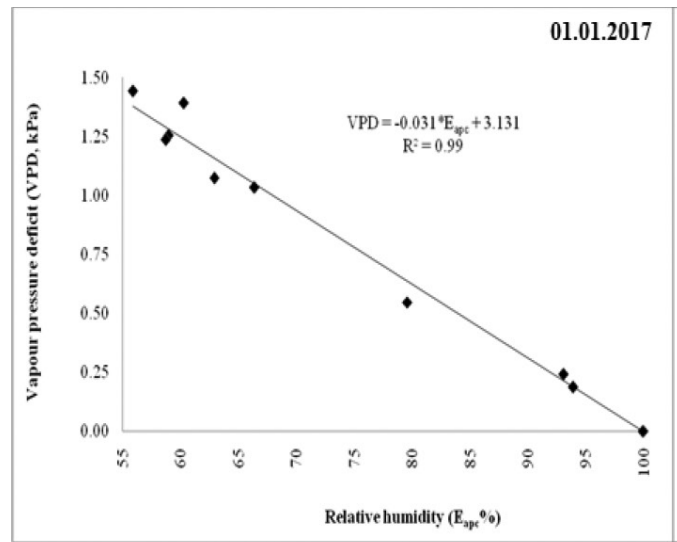

(a)

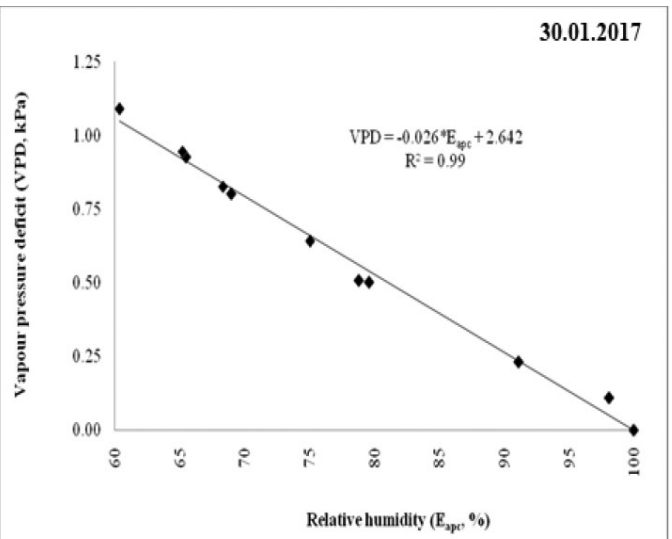

(b)

Fig. 6: Variation of VPD with $E_{\text {apc }}$ on a) 01.01.2017 and b) 30.01.2017

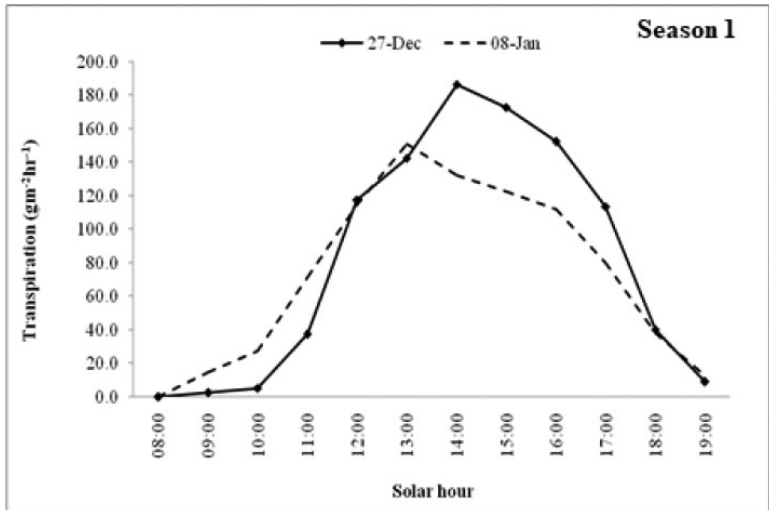

(a)

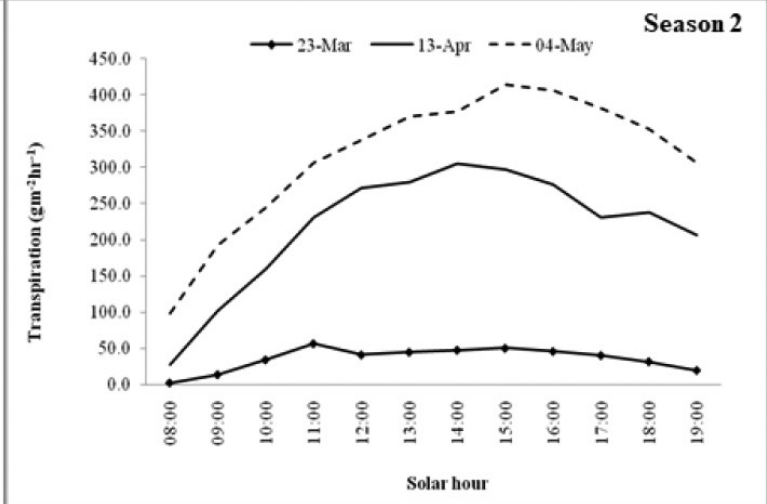

(b)

Fig. 7: Diurnal variation of crop transpiration during season 1 and season 2

weather conditions too.

The extremely low values of day time $\mathrm{E}_{\text {apc }}$ of greenhouse air encouraged the supply of nutrient solution to the crop. Similar effect of low $\mathrm{E}_{\mathrm{apc}}$ has laso been discussed in Yang et al. (1989). In the present study, the optimal range of $\mathrm{T}_{\mathrm{apc}}, \mathrm{E}_{\mathrm{apc}}, \mathrm{I}_{\mathrm{rad}}$ and VPD were projected based on microclimate modeling (Table 4). Fig. 5 indicates a linear relationship between transpiration and VPD. Such relationship between VPD and crop transpiration has already been reported in past (Medrano et al., 2005). Transpiration varied linearly with VPD even for values higher than $3.5 \mathrm{kPa}$ and such variation in crop transpiration with VPD has also been reported in Medrano et al. (2005). Further, the transpiration was the factor considered for fertigation scheduling, which can be helpful in improving irrigation management in crops grown in soilless media under polyhouse conditions (De
Boodt and Verdonck, 1972). Apart from this, there exists a relationship between VPD and transpiration in relation to prevailing climatic conditions such as wind speed and rate of ventilation.

\section{CONCLUSIONS}

The VPD indicated an increasing trend with $\mathrm{T}_{\text {apc }}\left(\mathrm{R}^{2} \geq 0.84\right)$ and decreasing trend with $\mathrm{E}_{\text {apc }}\left(\mathrm{R}^{2}=0.99\right)$ with a strong positive correlation. Crop transpiration in relation to VPD was significantly affected by $\mathrm{T}_{\mathrm{apc}}, \mathrm{E}_{\mathrm{apc}}$ and $\mathrm{I}_{\mathrm{rad}}$. The increasing crop transpiration with VPD, mainly during hot climatic conditions significantly increased the water input or fertilizer (nutrient solution) use in soilless cultivation systems. Thus, transpiration in relation to VPD should be considered as a factor for fertigation scheduling and improving irrigation control in soilless systems. Moreover, maintaining $\mathrm{T}_{\mathrm{apc}}, \mathrm{E}_{\mathrm{apc}}$ and VPD within range of 


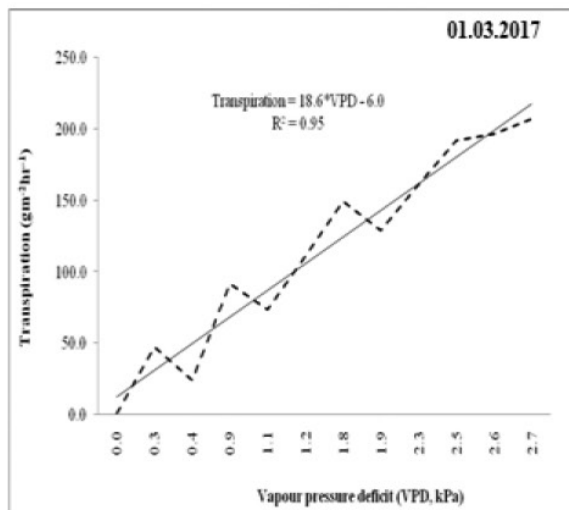

(a)

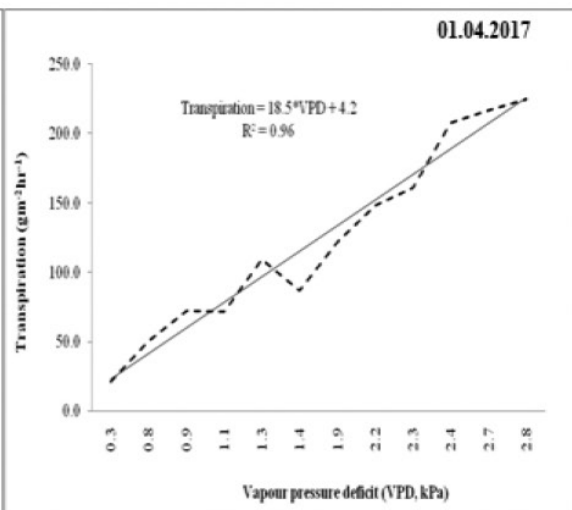

(b)

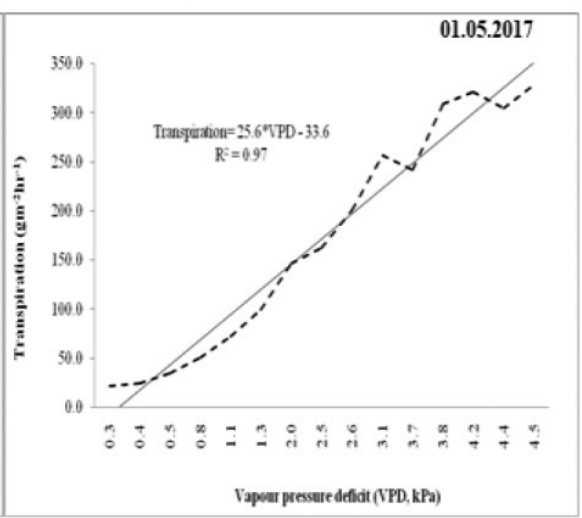

(c)

Fig. 8: Variation of transpiration with VPD on a) 01.03 .202017 , b) 01.04 .17 \& c) 01.05 .2017

$22-27^{\circ} \mathrm{C}, 60-80$ per cent and $0.53-1.10 \mathrm{kPa}$, respectively may help to control the crop transpiration, manage the greenhouse irrigation and fertigation, and thus improve the cucumber yield. Furthermore, the developed web based computer module can be successfully utilized for generating graphical representation of VPD in the form of Excel Chart for its easy depiction.

\section{ACKNOWLEDGEMENT}

The authors acknowledge the financial support from the funding agency (ICAR, New Delhi) under AICRP Project on PET.

Conflict of Interest Statement: The author(s) declare(s) that there is no conflict of interest.

Disclaimer: The contents, opinions, and views expressed in the research article published in the Journal of Agrometeorology are the views of the authors and do not necessarily reflect the views of the organizations they belong to.

Publisher's Note: The periodical remains neutral with regard to jurisdictional claims in published maps and institutional affiliations.

\section{REFERENCES}

Arellano, M.A., Garcia, S., Sanchez, A., Soria-Ruiz, J., Valera, D.L. and Urrestarazu, M. (2006). Greenhouse microclimate and its natural variation in two subtypes of an almeria greenhouse. Acta Hort., 719: 147-156.
Bakker, J.C. (1991). Leaf conductance of four glasshouse vegetable crops as affected by air humidity. Agric. For. Meteorol., 55: 23-36.

Deiveegan, M., Pazhanivelan, S., Panneerselvam, S. and Setiyono, T.D. (2019). Modelling the spatial level yield variability of groundnut (Arachis hypogea) in rain fed districts of Tamil Nadu using crop simulation model. J. Agrometeorol., 21 (S-1): 211-217.

El-Aidy, F. (1990). The effect of planting date, density, variety and shade on production of cucumber under tunnels. Acta Hort., 287: 281-287.

Jolliet, O. and Bailey, B.J. (1992). The effects of climate on tomato transpiration in greenhouses: measurements and models comparison. Agric. For. Meteorol., 58: 43-62.

Kumar, S., Attri, S.D., Soni, A.K., Vishnoi, L., Singh, K.K., Sharma, G. and Tripathi, J.N. (2019). Satellite derived crop coefficient and crop water stress for soybean in semi-arid region of India. $J$. Agrometeorol., 21 (S-1): 140-146.

Medrano, E., Lorenzo, P., Sanchez-Guerrero, M.C. and Montero, J.I. (2005). Evaluation and modelling of greenhouse cucumber-crop transpiration under high and low radiation conditions. Sci. Hort., 105: 163-175.

Nederhoff, E.M., Rijsdijk, A.A. and de Graaf, A. (1992). Leaf conductance and rate of crop transpiration 
of greenhouse grown sweet pepper (Capsicum annuum L.) as affected by carbon dioxide. Sci. Hort., 52: 283-301.

Singh, M.C., Singh, J.P. and Singh, KG. (2017). Optimal operating microclimatic conditions for drip fertigated cucumbers in soilless media under a naturally ventilated greenhouse. Indian J. Ecol., 44: 821-826.

Singh, M.C., Singh, J.P. and Singh., K.G. (2018). Development of a microclimate model for prediction of temperatures inside a naturally ventilated greenhouse under cucumber crop in soilless media. Comput. Electron. Agric., 154: 227-238.
Srivastava, N.N., Rao, V.U. M., Korwar, G.R. and Venkateswarlu, B. (2010). Micro-level spatial variability and temporal trends in reference evapotranspiration (ETo) at a semi-arid tropical station. J. Agrometeorol., 12 (2): 208-212.

Sumathi, T., Ponnuswami, V. and Selvi, B.S. (2008). Anatomical changes of cucumber (Cucumis Sativus L.) leaves and roots as influenced by shade and fertigation. Res. J. Agric. Bio. Sci., 4: 630-638.

Yang, X., Short, T.H., Fox, R.D. and Bauerle., W.L. (1989). The microclimate and transpiration of a greenhouse cucumber crop. Transanctions of ASAE, 32: 2143-2150. 